\title{
The effect of starvation on the metabolic rate and microanatomy of Galumna elimata (Acari: Oribatida)
}

\author{
JAN HUBERT ${ }^{1}$ and VLADIMÍR ŠUSTR ${ }^{2}$ \\ ${ }^{1}$ Research Institute of Crop Production, Drnovská 507, Praha 6, CZ-161 06, Czech Republic; e-mail: hubert@hb.vurv.cz \\ ${ }^{2}$ Institute of Soil Biology, Czech Academy of Sciences, Na sádkách 7, České Budějovice, CZ-370 05, Czech Republic; e-mail: \\ sustr@upb.cas.cz
}

Key words. Acari, Galumna elimata, starvation, mortality, fresh mass, respiration, amylase, microanatomy, gut

\begin{abstract}
The physiological parameters mortality, mass, oxygen consumption and amylase activity, and microanatomical features of the digestive tract, mesenchym and reproductive organs were used to characterise starvation in Galumna elimata. The mites were reared in sterilised plastic vials containing moistened zeolite at $25^{\circ} \mathrm{C}$ and a $12: 12$ photoperiod. The control group was kept under the same conditions, but pieces of bark covered with the green bark alga, Desmococcus vulgaris (syn. Protococcus viridis), were added as food for the mites. The physiological parameters were recorded after 21 days, and the microanatomical after 21 and 42 days. The guts of the starved mites were empty or filled with mucoid substances, while the guts of control mites contained food boli formed from algal cells. The mortality was significantly higher in starved animals. The mortality after 42 days of starvation was higher in males than females. The fresh mass of starved individuals significantly decreased while the water proportion content of their body tissues increased. Oxygen consumption of the starved mites was lower. Starvation did not influence the activity of amylase. Glycogeneous granulae were characteristically absent, and mucoid substances present in the guts of mites starved for 21 days. The activity of mesenteral and caecal cells, proventricular glands and cells of salivary glands was reduced after 42 days of starvation. The cells of the seminal vesicles were reduced and contained no spermatic cells in males starved for 42 days. Starved females probably resorbed immature oocytes, but had eggs in their oviducts. Starvation induces ovovivipary or larvipary in Galumna elimata.
\end{abstract}

\section{INTRODUCTION}

The feeding biology of oribatid mites has been intensively studied, especially the interactions between oribatids and the micro-organisms responsible for plant litter decomposition (reviewed by Wallwork 1983 and Seastedt 1984). In order to achieve a better understanding of the role of oribatids in soil systems and litter decomposition, several authors have described their feeding habits and assigned them to feeding guilds (Schuster, 1956; Luxton, 1972; Kaneko, 1988; Siepel \& Ruiter-Dijkman, 1993). However, the food resources used by oribatids in soil are difficult to investigate due to the heterogeneity of soil systems.

Many experiments and observations have been made on their feeding habits under laboratory conditions. In addition such information was also obtained from rearing experiments (Cleat, 1952; Sengbush, 1954; Woodring \& Cook, 1962a; Stefaniak \& Seniczak, 1976). Food preference tests were used by Wallwork (1958), Hartenstein (1962), Luxton (1972), Trávníček (1989), Siepel (1990), Rihani et al. (1995), and Maraun et al. (1998). The microorganisms have been identified and the structural changes that occurs in the food during its passage through the gut have been determined by dissection and the cultivation of gut contents (Schuster, 1956; Hoebel-Mävers, 1967; Behan \& Hill, 1978; Behan-Pelletier \& Hill, 1983; Smrž, 1992a; Smrž, 1996). The presence of digestive enzymes gives some information on the compounds they utilise (Zinkler, 1971 and 1972; Luxton, 1972; Dinsdale, 1974; Zinkler et al., 1986; Siepel, 1990; Siepel \& Ruiter-
Dijkman, 1993; Urbášek \& Starý, 1994; Šustr \& Starý, 1998).

It is not always easy to interpret these results because:

(i) The difficulty of establishing outdoor conditions indoors (Woodring \& Cook, 1962a).

(ii) Food preference tests are influenced by the spectrum of diets offered. Galumna elimata preferred the green bark alga, Desmococcus vulgaris, in the laboratory but this species is not present in soil (Hubert et al., 1999; Hubert \& Lukešová, 2001).

(iii) The quantification of food consumption (Saichuae et al., 1972) or defecation (Hubert et al., 1998) does not provide information about assimilation efficiency. Scheloribates laevigatus has a high defecation rate when fed Desmococcus algae and Penicillium spores, but the spores and some of the algal cells pass through the gut undamaged (Hubert et al., 1999; Hubert \& Lukešová, 2001). A higher food intake could compensate for energetically poor diets.

(iv) The presence of substrate specific enzyme activity indicates, but is not proof of substrate utilisation. For example, Achipteria coleoptrata and Scheloribates laevigatus differ in chitinase activity (Siepel \& RuiterDijkman, 1993), but neither species digest fungal cell walls, where chitin is the main compound (Hubert, in prep.). The physical and chemical conditions in the oribatid gut are unknown. Enzyme activity, measured in vitro, does not correspond to the amount of the substrate digested in vivo. There are indications that there are qualitative differences in the chitinase activity in two populations of Steganacarus magnus (see Smrž, 
1998). Scheloribates laevigatus mites reared in the laboratory differ from those collected in the field in their amylase activity (Hubert et al., 1999). The amylase activity of Galumna elimata changed due to thermal acclimation (Šustr \& Hubert, 1999). Such intraspecific changes in enzyme activity may be due to either a nutritionally poor diet or changes in temperature and therefore subject to misinterpretation.

Generally, the possibility of compensatory of digestive activity (at the level of food consumption as well as concentration of digestive enzymes) makes the differences between species difficult to interpret. Neither the most attractive (preferred in the laboratory tests) food nor the food consumed or defecated at the highest rate can be assessed as the most nutritionally suitable without knowing the efficiency with which it is assimilated. Even specific substrate enzyme activity is ambiguous if there is knowledge of intra-species variability and compensatory ability.

These problems are resolvable if very long term experiments are used in which the survival and reproductive success of a species feed a particular food are monitored. Another approach is to use more sensitive parameters of the energy budget in standard feeding experiments, and experimental investigations of the variability and physiological adaptations of oribatid digestion. Starvation represents an extreme feeding regime and could provide a useful model for such investigations.

The aim of this study is to describe the oribatid Galumna elimata tolerance of starvation, and the changes in body water content, respiration and digestive enzymes, and microanatomy of the digestive tract, mesenchyme, and reproductive organs that occur in this species during starvation. The objectives were to find physiological and microanatomical features that indicate starvation or a low energy intake.

\section{MATERIAL AND METHODS}

Galumna elimata (C. L. Koch, 1841) is a common oribatid mite in meadows in Central Bohemia (Czech Republic). The specimens originated from meadow soil collected near the centre of Říčany town, $20 \mathrm{~km}$ east from Prague, $406 \mathrm{~m}$. a. s. 1 . The samples were collected in October and November 1999 Mites were extracted using modified Berlese-Tullgren apparatus (extraction temperature was $35^{\circ} \mathrm{C}$, water was as the collecting fluid and was replaced daily for 5 days). The adults were kept in plastic vials (volume $250 \mathrm{ml}$ ), the bottoms of which contained plaster of Paris. The vials were stored in a refrigerator (at $8^{\circ} \mathrm{C}$ ) for one week before the start of the experiments.

Two groups of oribatids were established: starved mites and a control group fed on the green bark algae, Desmococcus vulgaris (syn Protococcus viridis). Galumna mites are able to complete their life cycle on this food (Sengbusch, 1954). Algae is a more attractive food for Galumna elimata than plant litter (Hubert, in prep.). Both groups were reared in plastic vials containing $15 \mathrm{~g}$ of sterilised zeolite (Chemko ${ }^{\circledR}$, Slovakia) moistened with $10 \mathrm{ml}$ of sterilised distilled water, and remoistened weekly. The vials were kept in a controlled regime $(12 \mathrm{~L}: 12 \mathrm{D}$ hours, temperature $25^{\circ} \mathrm{C}$ ).

\section{Experiments:}

\section{(1) Mortality}

Both the starved and the control groups consisted of 6 rearing chambers, each represented by a vial with 18 individuals. After 21 and 42 days these individuals were placed into Petri dishes, the bottoms of which were lined with moistened filter paper, and observed. A circle (diameter $1 \mathrm{~cm}$ ) was drawn on the filter paper and the mites placed in this circle. The mites found in the circle after twelve hours were classified as dead. The differences in mortality of the control and starved groups were tested by $\log$ linear analysis (weighted by the number of individuals in each group) within Splus ${ }^{\circledR}$

\section{(2) Mass of individuals.}

The living individuals were weighed (one sample usually contained 16 individuals) on a microbalance (R160P - Sartorius $\mathbb{B}$; accurate to $0.01 \mathrm{mg}$ ). The six replicates were per experimental group. Samples were dried at $110^{\circ} \mathrm{C}$ for 4 hours and weighed again to obtain the dry mass. Water content was calculated as the difference between fresh and dry mass. The mass differences were tested using the non-parametric Kruskal-Wallis test (Statgraphics $(\mathbb{B})$.

\section{(3) Respiration.}

A modification of the manovolumetric respirometer was used for the respirometric measurements. Verdier (1983) described its theory, based on the differential equation of the gas law. The length of the fluid column in a glass capillary of a given cross sectional area depends on the pressure and volume changes occurring thin the respirometric cell. One millimetre of displacement corresponds to $0.01 \mu \mathrm{l}$. The apparatus consists of a thermostatically controlled airtight water bath with several respirometric units almost completely submerged in the water. Every respirometric unit consists of glass capillary (internal diameter about $0.2 \mathrm{~mm}, 30 \mathrm{~cm}$ in length). The upper end of the capillary leads into the reservoir of manovolumetric fluid (xylene), which is open to the internal air of the bath. The bottom (submerged) end of the capillary leads into the respirometric cell. The respirometric cell is divided by a fine net into a space for the animal and one for the $\mathrm{CO}_{2}$ absorbent $(10 \mu 1$ of $0.1 \mathrm{~N} \mathrm{KOH}$ ). One circle of filter paper ( $3 \mathrm{~mm}$ diameter), wetted with distilled water, was used to maintain a high humidity in the respirometric cell.

Each respirometric unit was loaded with $\mathrm{KOH}$, a moist piece of filter paper and test animals (16 individuals) seated and then these units plus several control ones (without animals), were incubated for 30 minutes in the bath before the measurements began. Then the reservoirs of the units were quickly filled with $2 \mathrm{ml}$ of the manovolumetric fluid, and the bath was hermetically closed. The start position of the meniscus of manovolumetric fluid was recorded after 5 minutes, and then regularly at 20 minute intervals. The respiration rate was measured at a constant temperature $\left(20 \pm 0.02^{\circ} \mathrm{C}\right)$ for 2 hours. The mites were weighed on a R $160 \mathrm{P}$ microbalance (Sartorius) immediately after the measurement. Oxygen consumption rate (M) was calculated as $\mathbf{M}=\mathbf{s . d l} .\left(\mathbf{K}+\mathbf{K}^{\prime} . \mathbf{L}\right)$, where $\mathbf{K}$ and $\mathbf{K}^{\prime} . \mathbf{L}$ are experimental data, which take into account initial parameters such as pressure, volume and temperature, $\mathbf{s}$ is the inner diameter of the capillary tube and $\mathbf{d l}$ is the change in the length of a fluid column in a tube. Respiration rate was expressed in live-mass specific units $\left(\mathrm{ml} \mathrm{O}_{2} \cdot \mathrm{g}^{-1} \cdot \mathrm{h}^{-1}\right)$ of the starved $(7$ replicates $)$ and control ( 9 replicates) groups after 21 days. Non-parametric Kruskal-Wallis test (Statgraphics(B) was used to evaluate the differences between the groups. 
(4) Activity of digestive enzymes.

Amylolytic (EC 3.2.1.1) activity was assayed after 21 day. Whole-body homogenates of 64 living mites were used, with 12 replicates per group. The mites were weighed and homogenised in $2.5 \mathrm{ml}$ of phosphate (Britton-Robinson) buffer $(\mathrm{pH} 7)$ and centrifuged ( $6000 \mathrm{rpm}, 7 \mathrm{~min})$. The $\mathrm{pH}$ optimum of Galumna elimata amylase was 7 (Šustr, unpublished). The S-Test using specific chromolytic substrates (Institute of Chemistry Bratislava, Slovakia) was used for the amylase assays (see Šustr \& Hubert 1999). The catalytic activities of the enzymes were expressed in $\mathrm{mg}$ of decomposed substrate per hour per $1 \mathrm{~g}$ of fresh oribatid body mass $\left(\mathrm{mg} \cdot \mathrm{h}^{-1} \cdot \mathrm{g}^{-1}\right)$. The significance of the difference between experimental groups was tested using nonparametric Kruskal-Wallis test (Statgraphics ${ }^{\circledR}$ ).

(5) Microanatomical observations.

Living individuals from both groups were fixed in modified Bouin-Dubosque-Brasil fluid (Smr $\square$, 1989) after 21 and 42 days. The fixed mites were embedded in paraplast, sectioned (thickness 5-7 $\mu \mathrm{m}$ ), and stained in Masson's triple stain.

\section{RESULTS}

The mortality of starved mites was significantly higher than of the control mites after 21 and 42 days (log-linear analysis, $\left.\chi^{2}=3223, \mathrm{P}<0.001\right)$ and mortality was higher after 42 days than after 21 days (log-linear analysis $\chi^{2}=$ $1909, \mathrm{P}<0.001$, Tab. 1). Galumna elimata mites in the control group fed intensively on the green bark algae, Desmococcus vulgaris. Juveniles were observed after 42 days in the control group, but not in the starved group.

Starvation significantly influenced the mass of individuals after 21 days. The mean fresh mass of fed individuals was $121 \mu \mathrm{g}$, dry mass $57 \mu \mathrm{g}$, and the water content $64 \mu \mathrm{g}$ (53\% of the fresh mass). The mean fresh mass of starved mites was lower $(113 \mu \mathrm{g})$. Their dry mass was $41 \mu \mathrm{g}$ and the water content about $63 \%$ (Fig.1). Water content was significantly $(\mathrm{P}=0.03)$ higher in the starved mites.

The respiration rate was significantly lower in the starved than in fed mites. The respiration rate was 240 $\mu 1 . \mathrm{g}^{-1} \cdot \mathrm{h}^{-1}$ in the fed individuals and $130 \mu \mathrm{l} \cdot \mathrm{g}^{-1} \cdot \mathrm{h}^{-1}$ (Fig. 2) after 21 days of starvation.

Starvation for 21 days did not influence the amylolytic activity. Mass specific amylolytic activity was 5903 $\mathrm{mg}^{-1} \cdot \mathrm{g}^{-1} \cdot \mathrm{h}^{-1}$ and $5762 \mathrm{mg}^{-1} \cdot \mathrm{g}^{-1} \cdot \mathrm{h}^{-1}$ in the control and starved group, respectively (Fig. 3).

The digestive tract of Galumna elimata (Figs. 4, 5) is similar to the digestive tract of the model species Ceratozetes cisalpinus (see Woodring \& Cook, 1962b) and Euzetes globulus (see Hoebel-Mävers, 1967).

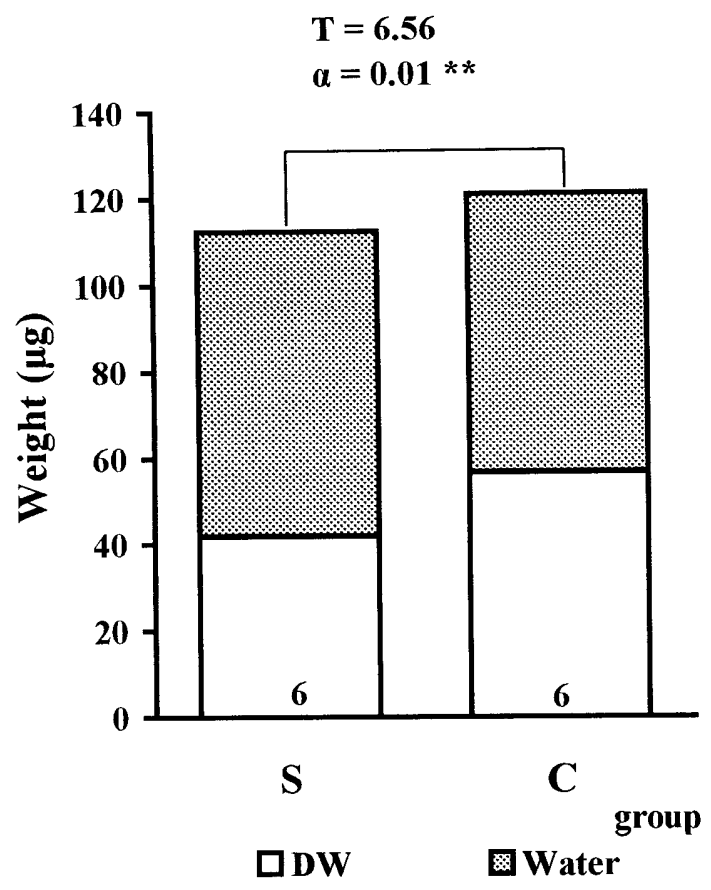

Fig. 1. Difference after 21 days in the mass of starved and control Galumna elimata. DW dry mass, Water mass of body water, $\mathrm{S}$ starved group, $\mathrm{C}$ control group. The numbers in column $=$ number of replicates.

All parts of the gut of the control mites contained algal food boli (Figs. 4, 5, 7). The guts of the starved mites were full of mucoid substances (Fig. 8) or empty (Fig. 6). After 42 days of starvation their tissues appeared reduced (Tab. 2, Fig. 6). Some fluid substances present in the salivary glands (Fig. 19), and mucoid substances in the caeca (Fig. 5) and by the mesenteral cells (Fig. 10). These substances were mixed with the ingested algal cells in fed individuals, or concentrated in the middle of mesenteron in starved individuals. In starved animals, the mucoid substances filled the whole mesenteron (Fig. 8) and more concentrated mucoid droplets formed boli (Fig. 9). The boli were passed through the gut into the rectum (Fig. 18). There were no structural differences in the mesenteral and faecal boli. After 21 days of starvation, individuals with mucoid boli prevailed over individuals lacking mucoid droplets in the mesenteron. Individuals lacking mucoid substances in the mesentron prevailed after 42 days.

Generally, mesenteral cells were thicker in the anterior than in the posterior part of the mesenteron of the control

TABLE 1. Mortality of starved and control Galumna elimata

\begin{tabular}{|c|c|c|c|c|}
\hline \multirow{2}{*}{$\begin{array}{l}\text { Period } \\
\text { Number of individuals that: }\end{array}$} & \multicolumn{2}{|c|}{21 days } & \multicolumn{2}{|c|}{42 days } \\
\hline & survived & died & survived & died \\
\hline Control group & 99 & 2 & 67 & 12 \\
\hline Starved group & 85 & 19 & 59 & 45 \\
\hline Analysis of deviance & Df. & Residual deviance & Df. (res. Dev.) & Deviance \\
\hline Null & & & 3 & $5,396.6$ \\
\hline Groups & 1 & $3,539.7$ & 2 & $1,856.8$ \\
\hline Periods & 1 & $1,708.8$ & 1 & 148.1 \\
\hline
\end{tabular}




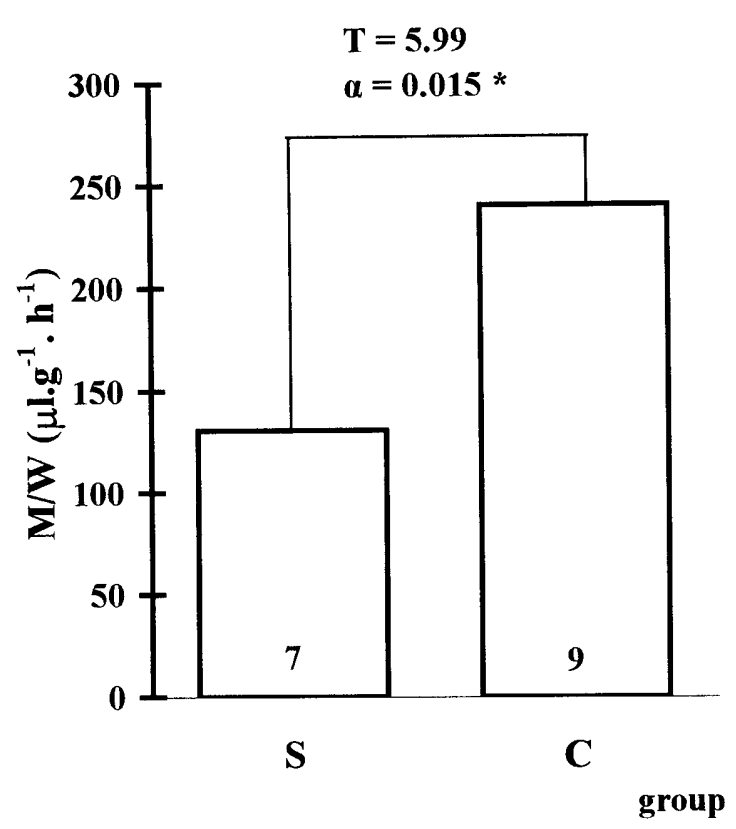

Fig. 2. Difference after 21 days in respiration of starved and control Galumna elimata. M/W mass specific oxygen consumption, $\mathrm{S}$ starved group, $\mathrm{C}$ control group, the numbers in column $=$ number of replicates.

mites. The cells were filled with dark stained granules (Fig. 10). There were green stained microvilli on the apical parts of the cells. The nuclei were relative large and well stained. These cells produced little apocrine secretion compared to the control specimens, there were fever granulae in the cells, and the thickness of mesenteral cells was not reduced after 21 days of starvation (Fig. 11). After 42 days, the mesenteral cells were very thin, and the nuclei still lacked dark stained granulae. No microvilli were observed (Fig. 12). The caecal cells in control individuals exhibited intense apocrine secretion (Fig. 13). The cells were strongly vacuolized and produced mucoid substances and large green stained spherical granulae. The caeca of mites starved for 21 days were similar to those of the control group, only lacking green granulae (Fig. 14). After 42 days of starvation, the cells of caeca were thinner and poorly vacuolized and lacked apocrine secretion (Fig. 18).

The cells of the colon (Fig. 8) were similar to those of the model species (see Woodring \& Cook, 1962b; Hoebel-Mävers, 1967).

The rectum of control individuals had a reduced brush border (Fig. 16), while the rectum of animals starved for 21 days had a well-developed brush border (Fig. 17). The

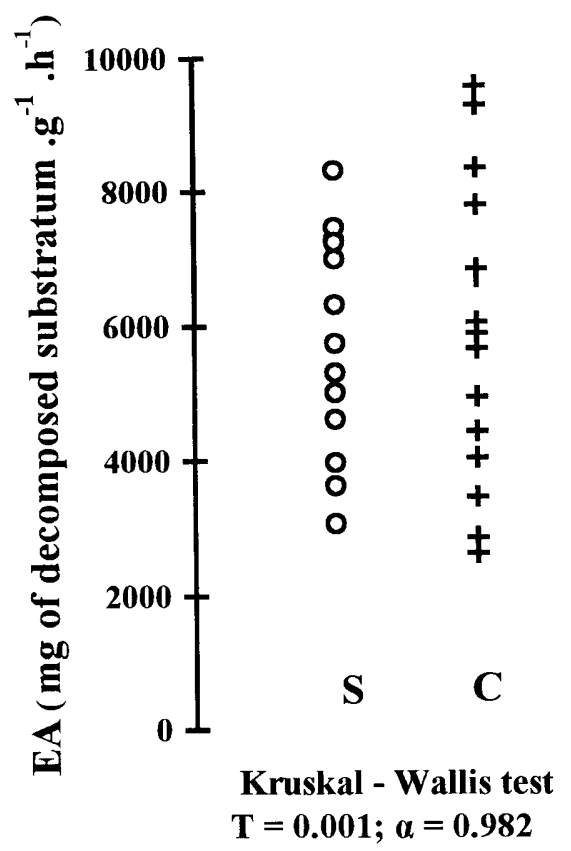

Fig. 3. A comparison after 21 days of the amylolytic activity in starved and control Galumna elimata. EA mass specific amylolytic activity, S starved group, $\mathrm{C}$ control group.

thickness of the colon and rectal cells, as well as their brush border were reduced after 42 days of starvation (Fig. 18).

The proventricular glands (for description see Šustr \& Hubert, 1999) were present in the majority of specimens from the control group and in some animals starved for 21 days, but apparently absent after 42 days of starvation.

The salivary glands were lobed. Some cells contained a large nucleus and vacuoles. Other cells in the lobes formed reservoirs. There were two kinds (physiological types) of salivary glands in control individuals; namely those without reservoirs with vacuolized cells (Fig. 19) and glands with well developed reservoirs. The second type prevailed in the starved mites (Fig 20).

The mesenchymal cells of control specimens contained glycogeneous granulae (Fig. 15). These glycogeneous granulae were not observed in starved mites, except for one gravid female that had been starved for 21 days. Extra-intestinal bacteria were observed in one specimen starved for 21 days (Fig. 21).

The male/female ratio tended to $1: 1$, however females prevailed over males after 42 days of starvation. Testes and seminal vesicles were not different from those of the model species Ceratozetes cisalpinus (see Woodring \&

Figs 4-12. 4 - Galumna elimata, control group - sagital section; 5 - horizontal section; 6 - horizontal section of an individual starved for 42 days; 7 - intensive consumption of algae by control individual; 8 - mesenteron of an individual starved for 21 days filled with mucoid substances of; 9 - mucoid bolus in an individual starved for 21 days; 10 - mesenteron of a control individual, the arrows point to mucoid package of food; 11 - apocrine secretion in the mesenteron of an individual starved for 21 days; 12 - mesenteron of an individual starved for 42 days. Abbreviations used: $\mathrm{c}$ - colon, ca - caecum, $\mathrm{cm}$ - cheliceral muscles, cu - cuticle, e egg, $\mathrm{fb}$ - food bolus, $\mathrm{m}$ - mesenteron, mc - mesenteral cell, $\mathrm{md}$ - mucoid droplets, $\mathrm{ms}$ - mucoid substances, mu - muscles, o oesophagus, $\mathrm{ph}$ - pharynx, $\mathrm{r}$ - rectum, sg - salivary glands, syn - synganglion. Scales: $0.1 \mathrm{~mm} \ldots$. 4-6; 0.5 mm ...7-9; 0.025 mm...10-12. 


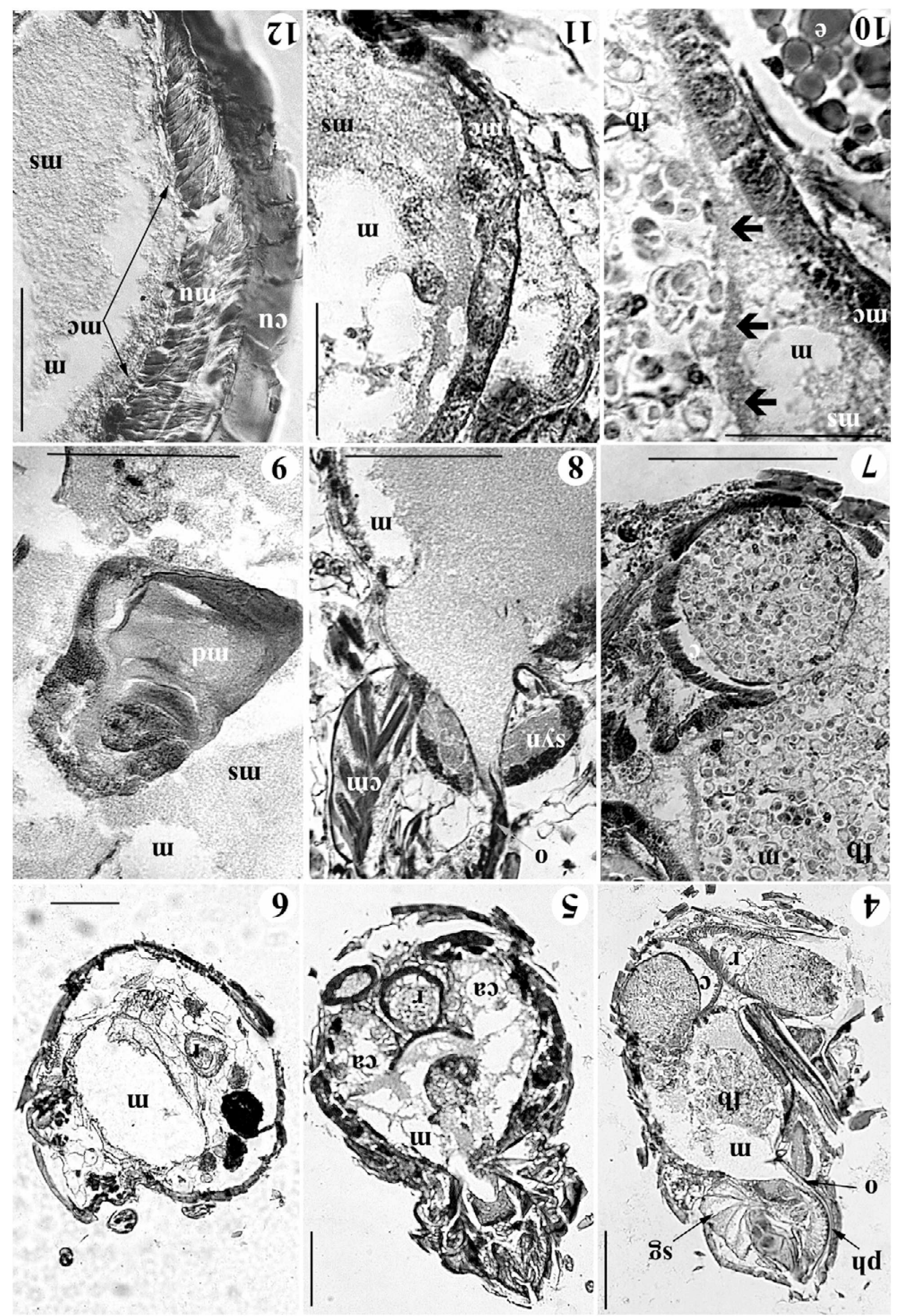


TABLE 2. Micronatomical differences of starved and control Galumna elimata. + - present; - absent; ++ indicate higher intensity; I salivary glands without reservoirs with vacuolized cells; II glands with well developed reservoirs.

\begin{tabular}{|c|c|c|c|c|}
\hline \multirow{2}{*}{ Parametres } & \multicolumn{2}{|c|}{ Control group } & \multicolumn{2}{|c|}{ Starved group } \\
\hline & 21 days & 42 days & 21 days & 42 days \\
\hline Reduction of tissues & - & - & - & + \\
\hline \multicolumn{5}{|l|}{ Mesenteral cells } \\
\hline Density of granulation & ++ & ++ & + & - \\
\hline Thickness & ++ & ++ & ++ & + \\
\hline Microvilli & + & + & + & - \\
\hline \multicolumn{5}{|l|}{ Caecal cells } \\
\hline Density of granulation & ++ & ++ & ++ & + \\
\hline Green stained granulae & + & + & - & - \\
\hline Thickness & ++ & ++ & ++ & + \\
\hline Apocrine secretion & + & + & + & - \\
\hline \multicolumn{5}{|l|}{ Colon cells } \\
\hline Thickness & ++ & ++ & ++ & + \\
\hline \multicolumn{5}{|l|}{ Rectal cells } \\
\hline Thickness & ++ & ++ & ++ & + \\
\hline Brush border & + & + & ++ & + \\
\hline Proventricular glands & ++ & ++ & + & - \\
\hline Food bolus & + & + & - & - \\
\hline Type of salivary gland & I, II & $\mathrm{I}, \mathrm{II}$ & I, II & II \\
\hline Glycogenous inclusions & ++ & ++ & + & - \\
\hline \multicolumn{5}{|l|}{ Seminal vesicles } \\
\hline Lentiform spermatics cells & + & + & + & - \\
\hline Thickness & ++ & ++ & ++ & + \\
\hline \multicolumn{5}{|l|}{ Eggs } \\
\hline Number & ++ & ++ & ++ & ++ \\
\hline Germ cells & - & - & - & + \\
\hline
\end{tabular}

Cook, 1962b) and Trichoribates trimaculatus (see Smrž, 1992a). As in the model species Trichoribates trimaculatus (see Smrž, 1992a), the reproductive tract of females contained all stages of oogenesis including eggs (Fig. 22). The number of eggs was not influenced by starvation. A higher number of germ cells in the embryos was recorded after 42 days of starvation (Figs 23, 24). Clumps of cells (Fig. 25) with large nuclei were observed in the ovaria of some females starved for 42 days. All males in the control group and those starved for 21 had lenticular spermatic cells in their seminal vesicles (Fig. 26). The seminal vesicle cell walls were rather thin, and dark staining with large nuclei in control individuals. Vacuolization of these cells was not observed. No spermatic cells were observed in the seminal vesicles of the group starved for 42 days
(Fig. 27). The seminal vesicle cells were thinner than in the controls and those starved for 21 days. The testes were not reduced.

\section{DISCUSSION}

The hypothetical maximum time for which Galumna elimata can survive when starved must be shorter than the period estimated from its energy reserves and metabolic rate: Wallwork (1975) gives a mean energy reserves for oribatid mites of $19.8 \mathrm{kJg}^{-1}$. The energetic equivalent in respiration is $0.02 \mu \mathrm{O}_{2}$. The energy content of Galumna elimata at the beginning of starvation is $\mathrm{E}=19.8 \mathrm{~kJ} \cdot \mathrm{g}^{-1} \times$ $0.00006 \mathrm{~g}=1.18{\mathrm{~J} . \mathrm{ind}^{-1}}^{-}$. The respiration rate of a starved individual was $\mathrm{R}=0.378 \times 0.02=0.0076 \mathrm{~J}$.ind $\mathrm{d}^{-1}$. day ${ }^{-1}$. Thus, the maximum period for which they can survive $=$

Figs. 13-21. 13 - caecum of a control individual (arrows point to proliferated parts of the cells); 14 - caecum of an individual starved for 21 days (arrows point to proliferated parts of the cells); 15 - glycogeneous inclusions (indicated by arrows) in the mesenchyme of a control individual; $16-18$ - rectum (brush border is indicated by arrows); 16 - control individual; 17 - individual starved for 21 days; 18 - individuals starved for 42 days; 19 - salivary glands of control individual (empty arrows indicate nuclei, black arrows vacuoles); 20 - salivary glands of an individual starved for 21 days; 21 - extra-intestinal bacteria in a starved individual. Abbreviations used: ca - caecum, cc - caecal cells, cu - cuticle, eb - extra-intestinal bacteria, feb - faecal bolus, $m$ - mesenteron; $\mathrm{ms}$ - mucoid substances, o - oesophagus, $\mathrm{r}$ - rectum, rc - rectal cell, $\mathrm{rs}$ - reservoir of salivary gland, sg - salivary glands, syn - synganglion. Scales: $0.025 \mathrm{~mm} \ldots 13-17 ; 0.05 \mathrm{~mm} \ldots .18-21$. 


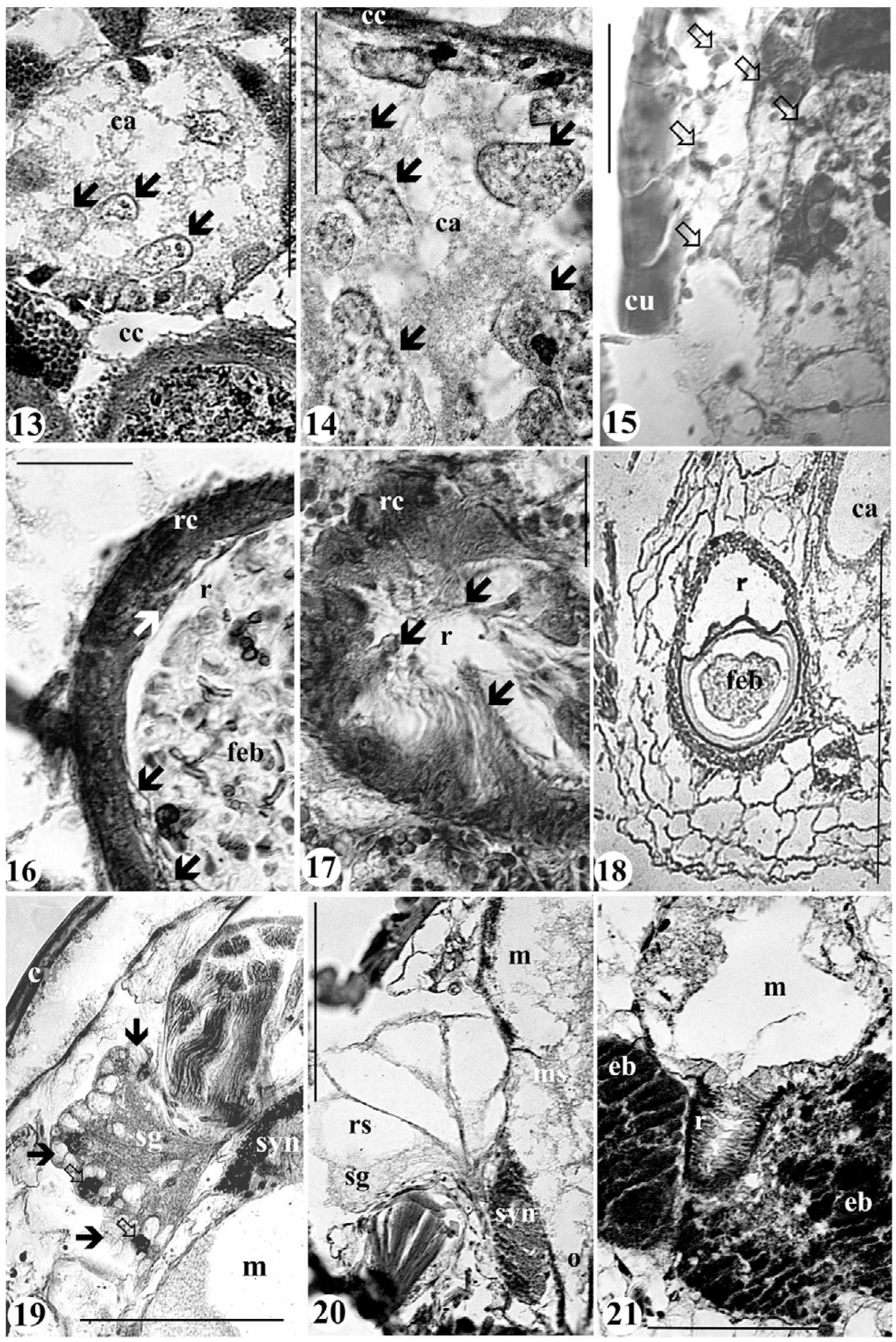




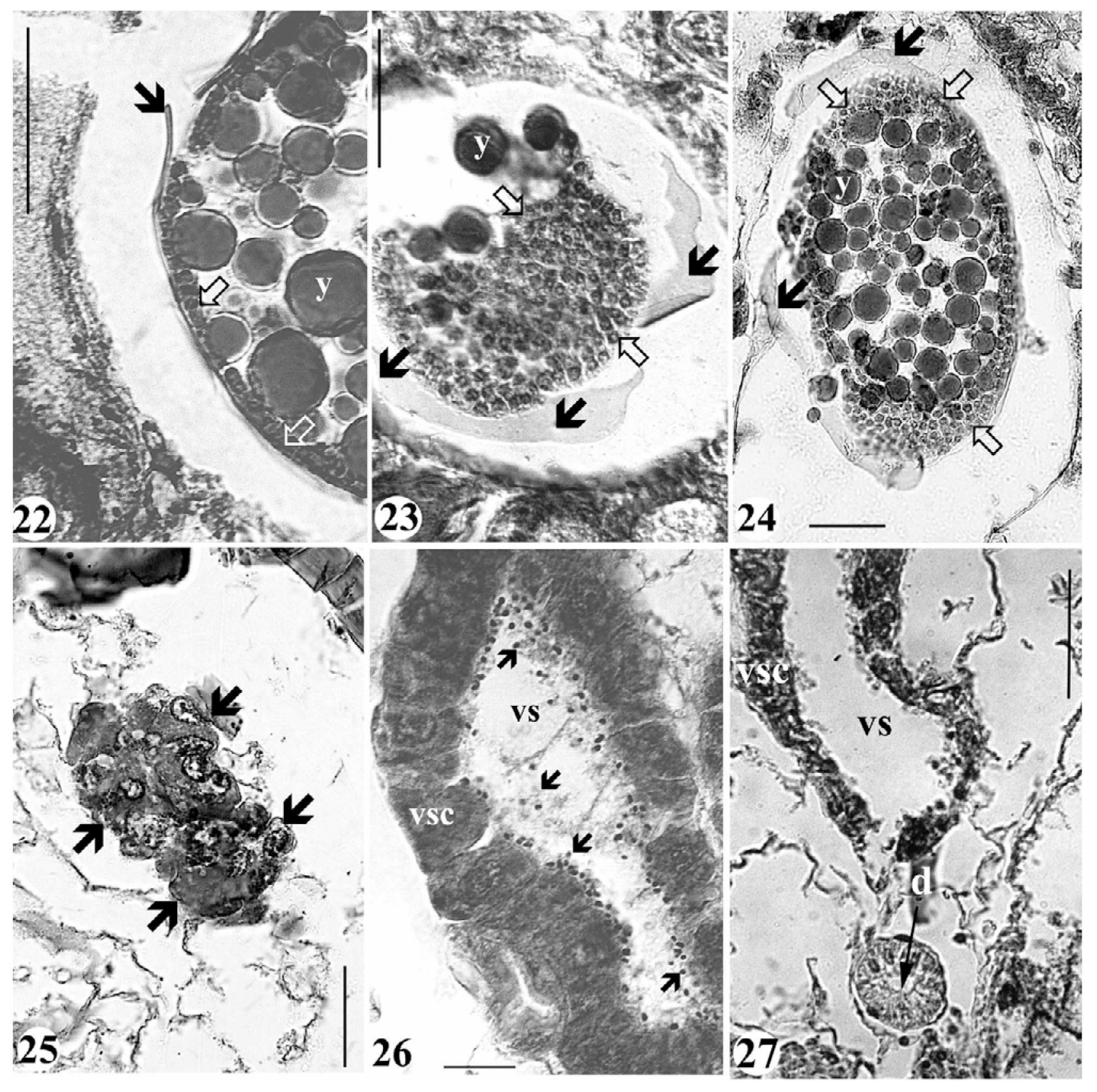

Figs 22 - 27. 22 - 24 - female reproductive system (empty arrow indicates germ cells, black arrow chorion). 22 - control; 23 24 - a female starved for 42 days; 25 - ovarium of 42 days starved female (arrows point to clumps of cells); $26-27$ - seminal vesicles; 26 - control (arrows point to spermatic cells); 27 - a male starved for 42 days. Abbreviations used: $\mathrm{d}$ - vas deferens, vs seminal vesicles, vsc - cell of seminal vesicles, $y$-yolk. Scales: $0.025 \mathrm{~mm} \ldots .22-25 ; 0.05 \mathrm{~mm} \ldots .26,27$.

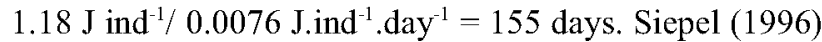
observed $10 \%, 50 \%$ and $90 \%$ mortality after 25,49 and 96 days of starvation, respectively, in a related species of oribatid Galumna lanceata. It may be difficult to detect a significant increase in mortality in animals supplied with insufficient food for period shorter than 21 days.

An empty mesenteron or one filled with a mucoid bolus could be due to (i) the short period of time necessary for the passage of food through the gut, or (ii) starvation. In the case of the former, food or faecal boli are usually present in the colon or rectum (Smrž, 1992a). In the present study, the whole gut of starved individuals was empty or contained mucoid boli. However, a full gut is not a useful indicator of sufficient energy input, if energetically poor or indigestible food is consumed. Smrž \& Materna (2000) suggested that a mucoid bolus be called a food bolus. If fluid food is ingested it could not be distinguished from the mucoid substances produced by the mites. Fluid food could be sucked from hyphae, for example. However our results indicate that the mucoid substances do not arise from the ingestion of fluids, but are produced by 
Galumna elimata and do not contain any food particles. The mucoid bolus is not a food bolus in this case.

The decrease in respiration rate and dry body mass indicate energy deficiency in Galumna elimata after 21 days of starvation. These parameters could be used as indicators of food suitability.

If palatable food is of sufficient quality, the nutrients could be stored as energy rich deposits (Smrž \& Materna, 2000 ). The energy deficiency resulted in a decrease in the amount of some storage compounds (glycogeneous granulae) after 21 days of starvation. The females have a higher density of glycogeneous granulae than the males (Smrž \& Materna, 2000). The rapid reduction in glycogeneous granulae started in both males and females at the onset of starvation. The females had more of glycogeneous granulae at the start of the experiment, so their glycogen reserves lasted longer. Glycogeneous granulae were present in gravid females after 21 days of starvation but not after 42 days of starvation. After 42 days both sexes lacked glycogeneous granulae. The amount of glycogen could be an important early indicator of starvation in Galumna elimata (cf. Smrž \& Materna, 2000).

The mesenteral and caecal cells, and salivary glands produce some digestive enzymes (Dinsdale, 1974). Smrž (1992a) observed and discussed the correlation between the density of dark granulation in the mesenteral cells (enzyme production), and the intensity of the digestive processes in terms of speed digestion and utilisation. Starvation influenced the quantity of dark granulae in the mesenteral cells, however, it did not influence the amylolytic activity. So, amylase activity is not directly related to the production of dark granulae in the mesenteral cells. Amylase may be produced in the salivary glands, whose reservoirs were well developed in the starved mites. No difference in amylolytic activity and of other enzymes was found in Scheloribates laevigatus fed on various diets in the laboratory (Hubert et al, 1999).

The difference in the rectal brush border between starving and fed individuals is related to water absorption (see Smrž, 1992a). The passing of an algal food bolus requires little time, and this food probably provided Galumna elimata with water, so the brush border could be reduced. A similar reduction is observed in Scheloribates laevigatus fed on algal diets (Hubert \& Lukešová, 2001). The well developed brush border present after 21 days of starvation may be related to effective water absorption. However, the higher mean water content of starved mites contradicts to this explanation. All absorption mechanisms (including water absorption) might show on increase in efficiency in the initial period of starvation and result in the higher water content in starved mites. The efficiency of absorption may be reduced again later in order to save energy.

All other changes may be late indicators of starvation, which appear when approaching the $\mathrm{LT}_{50}$ values. After 42 days of starvation, the reduction in cell contents and cell granulation in the mesenteron, colon and rectum were marked. These microanatomical features can be recom- mended for identifying starvation in long term experiments.

Although the production of mucoid substances in starved mites decreased, some starved individuals produced mucoid boli. This indicates the starved individuals produced the same substances as fed individuals (also see Sustr \& Hubert, 1999). The mucoid bolus could be formed just before food ingestion, and the ingested food particles are then packed in this mucus (cf HoebelMävers, 1967).

Starvation led to changes in the micromorphology of the reproductive tract and then reproduction is suppressed. The reduction in the size of the seminal vesicle cells and the absence of spermatic cells in the seminal vesicles is correlated with the high energy costs of maintaining spermogenesis. Under natural conditions spermatic cells are present in a high proportion of oribatid species throughout the year (Smrž, 1992a; Hubert \& Smrž, 1998). Thus this feature is a suitable indicator of starvation. The lower mortality of gravid females may be because they contained more storage compounds at the beginning of starvation. The origin of the clumps of cells in the oviducts of some of the starved females is unclear. They are probably partly reabsorbed oocytes, or aggregated hemocytes (cf. Smrž, 1995). This phenomenon is not reported for natural populations of mites (see Smrž, 1992a). The absence of juveniles as than starved indicates that there probably was no oviposition. In the laboratory. Scheloribates laevigatus females exhibit ovovivipary when fed filter paper, but the larvae died after a few days (Hubert, unpublished). The higher number of germ cells in the embryos of starved Galumna elimata females indicated ovovivipary. Larvipary and ovovivipary is reported in some oribatid mites (Wallwork, 1967; Webb \& Elmes, 1979; Hubert, 2000). Starved females of Galumna did not deposit eggs. In the soil, although females of most species have eggs in their oviducts throughout the year, oviposition occurred only after an environmental change (moisture, temperature) (Mitchell \& Parkinson, 1976; Luxton, 1981; Smrž, 1992b and 1994).

Reliable indications of starvation in oribatid mites, starved for relatively short periods are changes in respiration, dry body mass, glycogeneous granulae in mesenchymal tissue, gut contents and mortality. Significant changes in many microanatomical features and reproductive parameters only occur after prolonged periods (about 40 days) of starvation.

ACKNOWLEDGEMENTS. We thank to anonymous referees and Dr. Jan Žd'árek, Research Institute of Organic Chemistry and Biochemistry, ASCR for useful comments, Martina Žilová, Institute of Botany, ASCR for useful comments on an earlier draft and to Dr. Stano Pekár, Research Institute of Crop Production for his help with the GLM analysis.

This project was supported by grant No. 206/97/0629 of the Grant Agency of the Czech Republic. 


\section{REFERENCES}

BEHAN V.M. \& HiLl S.B. 1978: Feeding habits and spore dispersal of oribatid mites in the North American Arctic. Rev. Écol. Biol. Sol. 15: 497-516.

Behan-Pelletier V.M. \& Hill S.B. 1983: Feeding habits of sixteen species of Oribatei (Acari) from an acid peat bog, Glenamoy, Ireland. Rev. Écol. Biol. Sol. 20: 221-267.

Cleat N. 1952. Growth in the laboratory of economically important mites. Nature 169: 280.

DinsDALE D. 1974: The digestive activity of a phthiracarid mite mesenteron. J. Insect Physiol. 20: 2247-2260.

HARTENSTEIN R. 1962: Soil Oribatei I. - Feeding specificity among forest soil Oribatei (Acarina). Ann. Entomol. Soc. Am. 55: 202-206.

HoEBEL-Mävers M. 1967: Funktionsanatomische Untersuchungen am Verdauungstrakt der Hornmilben (Oribatei) Dissertation, Tech. Hochschule Carolo-Wilhelmina Braunschweig, Germany, $45 \mathrm{pp}$.

HưBert J. SMrž J. 1998: The internal anatomy of Scheloribates laevigatus (Acari: Oribatida). In Abstracts VI Eur. Congr. Entomol., Ceské Budějovice, 51 p.

Húbert J., Smrž J. \& Šurstr V. 1998: Feeding of oribatid mite Scheloribates laevigatus (Acari: Oribatida) in laboratory experiments. Preliminary results. In Pižl V. \& Tajovský K. (eds): Soil Zoological Problems in Central Europe. Ceské Budějovice. pp. 51-57

Hubert J., Šustr V. \& SmRž J. 1999: The feeding of Scheloribates laevigatus (Acari: Oribatida) under laboratory experiments. Pedobiologia 43: 328-339.

HuBERT J. 2000: Seasonal changes of abundance, sex ratio and egg production of Scheloribates laevigatus (Acari: Oribatida) in the soil of a meadow in the Czech Republic. Acta Soc. Zool. Bohemoslov. 64: 37-56.

Húbert J. Lukešová A. 2001: Feeding of the panphytophagous oribatid mite Scheloribates laevigatus (Acari: Oribatida) on cyanobacterial and algal diets in laboratory experiments. App. Soil Ecol. 16: 77-83.

KANEKO N. 1988: Feeding habits and cheliceral size of oribatid mites in cool temperate forest soils in Japan. Rev. Écol. Biol. Sol 25: 353-363.

Luxton M. 1972: Studies on the oribatid mites of a Danish beech wood soil - I. Nutritional biology. Pedobiologia 12: 434-463.

Luxton M. 1981: Studies on the oribatid mites of a Danish beech wood soil. IV. Developmental biology. Pedobiologia 21: $312-340$

Maraun M., Migge S., Schaefer M. \& Scheu S. 1998: Selection of microfungal food by six oribatid mite species (Oribatida, Acari) from different beech forests. Pedobiologia 42: 232-240.

Mitchell M.J. \& Parkinson D. 1976: Fungal feeding of oribatid mites in an aspen woodland soil. Ecology 57: 302-312.

Rihani M., KifFer E. \& Botton B. 1995: Decomposition of beech leaf litter by microflora and mesofauna. I. In vitro action of whiterot fungi on beech leaves and foliar components. Eur. J. Soil Biol. 31: 57-66.

Saichuae P., Gerson U. \& Henis Y. 1972: Observation on the feeding and life history on the mite Nothrus biciliatus (Koch). Soil Biol. Biochem. 4: 155-164.

Schuster R. 1956: Der Anteil der Oribatiden an den Zersetzungsvorgängen im Boden. Z. Morph. Ökol. Tiere. 45: $1-33$.

SEASTEDT T.R. 1984: The role of microarthropods in decomposition and mineralization processes. Anmu. Rev. Entomol. 29 25-46.
Sengbusch H.G. 1954: Studies on the life history of three oribatid mites with observations on other species (Acarina: Oribatei). Ann. Entomol. Soc. Am. 47: 646-667.

SIEPEL H. 1990: Niche relationships between two panphytophagous soil mites, Nothrus silvestris Nicolet (Acari, Oribatida, Nothridae) and Platynothrus peltifer (Koch) (Acari, Oribatida, Camisiidae). Biol. Fertil. Soils 9: 139-144.

SIEPEL H. 1996: The importance of unpredictable and short-term environmental extremes for biodiversity in oribatid mites. Biodiversity Letters 3: 26-34.

Siepel H. \& Ruiter-Dirkman E.M. 1993: Feeding guilds of oribatid mites based on their carbohydrase activities. Soil Biol. Biochem. 26: 1491-1497.

SMRŽ J. 1989: Internal anatomy of Hypochthonius rufulus (Acari: Oribatida). J. Morphol. 200: 215-230.

SMRŽ J. 1992a: Some adaptive features in the microanatomy of moss-dwelling oribatid mites (Acari: Oribatida) with respect to their ontogenetical development. Pedobiologia 36: 306-320.

SMRŽ J. 1992b: The ecology of the microarthropod community inhabiting the moss cover of roofs. Pedobiologia 36: 331-340.

SMRŽ J. 1994: Survival of Scutovertex minutus (Koch) (Acari: Oribatida) under differing humidity conditions. Pedobiologia 38: 448-454.

SMRŽ J. 1995: Free cells in the body cavity of oribatid mites. Pedobiologia 39: 488-495.

SMRŽ J. 1996: Some aspects of the life strategy of oribatid mites. In Mitchell R., Horn D. J., Needham G. R. Welbourn W. C. (eds): Acarology XI. Ohio Biological Survey, Columbus, Ohio, pp. 553-555.

SMRŽ J. 1998: Interaction between oribatids and microorganisms: A complex method of study. Appl. Soil Ecol. 9: 109-110.

Smrž J. \& MAterna J. 2000: The dynamics of glycogen deposition within the paranchyma tissue of Melanozetes meridianus (Acari: Oribatida). Pedobiologia 44: 175-185.

STEFANIAK O. \& SENICZAK S. 1976: The microflora of the alimentary canal of Achipteria coleoptrata (Acarina: Oribatei). Pedobiologia 16: 185-194.

Šustr V. \& STARÝ J. 1998: Digestive enzymes in oribatid mites: Impact of factors. In Pižl V. \& Tajovský K. (eds): Soil Zoological Problems in Central Europe. Proc. $4^{\text {th }}$ Central European Workshop, Inst. Soil Biol. Acad. Sci., Czech Republic, České Budějovice, 223-227.

ŚUSTR V. \& HubERT J. 1999: The influence of thermal acclimation on the amylolytic activity and microanatomy of the alimentary tract of oribatid mite Galumna elimata (Acari: Oribatei). Eur. J. Entomol. 96: 189-198.

TRÁVNíČEK M. 1989: Laboratory cultivation and biology of mites in the family Liacaridae (Acari: Oribatida). Acta Universitatis Carolinae Biologica 33: 69-80.

URBÁŠEK F. \& STARÝ J. 1994: The activity of some enzymes in the guts of five oribatid species (Acari, Oribatida). Pedobiologia 38: 250-253.

VERDIER B. 1983. Le respiromètre à pression et volume variables. Une technique simple et sensible pour l'étude écophysiologique des animaux du sol. In: Lebrun Ph., André H. M., DeMets A., Grégoire-Wibo C. \& Waughty G. (eds.): New Trends in Soil Biology. Proc. $8^{\text {th }}$ Int. Coll. Soil Zool., Louvain-la-Neuve (Belgium). Dieu-Brichart, OttigniesLouvain-la-Neuve, pp. 369-386.

WALLWORK J.A. 1958. Notes on the feeding behaviour of some forest soil Acarina. Oikos 9: 260-271.

WALLWORK J.A. 1967: Acari. In Burges A. \& Raw F. (eds): Soil Biology. Academic Press, London and N. Y, p. 149-196. 
WALLWORK J.A. 1975: Calorimetric studies on soil invertebrates and their ecological significance. In Vaněk J. (ed.): Progress in Soil Zoology. Proc. $5^{\text {th }}$ Int. Coll. Soil Zool., Prague. Academia, Praha, pp. 231-239.

WALLWORK J.A. 1983: Oribatids in forest ecosystems. Annu. Rev. Entomol. 28: 109-1130.

WeBb N.R. \& Elmes G.W. 1979: Variations between population of Steganacarus magnus (Acari: Cryptostigmata) in Great Britain. Pedobiologia 19: 390-401.

WoOdRING J.P. \& COOK E.F. 1962a: The biology of Ceratozetes cisalpinus Berlese, Scheloribates laevigatus Koch, and Oppia neerlandica Oudemans (Oribatei) with a description of all stages. Acarologia 4: 101-137.
WoOdRING J.P. \& CoOK E.F. 1962b: The internal anatomy, reproductive physiology, and moulting process of Ceratozetes cisalpinus (Acarina: Oribatei). Ann. Entomol. Soc. Am. 55: 165-181.

ZINKLER D. 1971: Carbohydrasen streubewohnender Collembolen und Oribatiden. C.R. IV. Colloque Faune du Sol, Dijon, pp. 329-334.

ZINKLER D. 1972: Vergleichende Untersuchungen zum Wirkungsspektrum der Carbohydrasen laubstreubewohnender Oribatiden. Verh. Dt. Zool. Ges. 65: 149-153.

ZinKLer D., Götze M. \& Fabian K. 1986: Cellulose digestion in "primitive insects" (Apterygota) and oribatid mites. Zool. Beitr. N.F. 30: 17-28.

Received November 23,2000; revised May 18, 2001; accepted June 1, 2001 